\title{
European oak powdery mildew: impact on trees, effects of environmental factors, and potential effects of climate change
}

\author{
Benoit Marçais • Marie-Laure Desprez-Loustau
}

Received: 19 April 2012 / Accepted: 6 November 2012 / Published online: 18 December 2012

(C) The Author(s) 2012. This article is published with open access at SpringerLink.com

\begin{abstract}
- Context Powdery mildew is one of the most common diseases of oaks in Europe. After alarming reports in the beginning of the twentieth century following the presumed introduction of the invasive fungus, the disease has become familiar to foresters. However, its impact may vary greatly according to intrinsic and extrinsic factors.

- Aims We aimed at providing updated and synthesised information on the impact of powdery mildew on oak and on the effects of environment on disease.

- Methods A comprehensive literature review was performed, including old reports of the early epidemics to more recent data.

- Results Tree growth patterns are of critical importance to explain the severity of the disease and the differences between juvenile and mature trees. A critical element, especially for infection of mature trees, is the availability of spores during the production of the first leaf flush. High disease impact is often related to modified growth patterns, either by environmental factors (insects or frost) or silvicultural practices (e.g., coppicing).

- Conclusion Powdery mildew can have important impacts in natural oak regenerations and a significant role in decline of

Handling Editor: Nathalie Breda

Contribution of the co-authors Both authors contributed in writing a part of the manuscript

B. Marçais $(\bowtie)$

INRA, Université de Lorraine, UMR1136 Interactions Arbres/Microorganismes, F 54280 Champenoux, France

e-mail: marcais@nancy.inra.fr

M.-L. Desprez-Loustau

UMR1202 BIOGECO, INRA, F 33610 Cestas, France

M.-L. Desprez-Loustau

UMR1202 BIOGECO, Univesrité de Bordeaux,

F 33400 Talence, France
\end{abstract}

mature trees. Climate change might influence the disease severity mainly by altering the host pathogen phenological synchrony. Process-based models are required for reliable predictions.

Keyword Erysiphe alphitoides; Quercus · Phenological synchrony $\cdot$ Oak decline $\cdot$ Natural regeneration

\section{Introduction}

Powdery mildew is one of the most common diseases of oaks in Europe. For example, it represented $13 \%$ of all biotic and abiotic health problems reported on deciduous oak species in France from 1989 to 2006 (database of the Département de la Santé des Forêts (DSF)). However, the disease was not reported in Europe before 1907 when sudden severe outbreaks were observed; the causal pathogen was then reported as invasive. It identity and origin was the subject of considerable debate in the years following the emergence of oak powdery mildew (reviewed in Mougou et al. 2008 and DesprezLoustau et al. 2011). The use of molecular tools has recently allowed more precise characterization of the causal agent. Mougou et al. (2008) showed that the same symptoms can be associated with four different powdery mildew lineages (probably cryptic species) currently co-existing in Europe. In a large survey in France, Erysiphe alphitoides, the species which was described in 1911, was the most common species (Mougou-Hamdane et al. 2010). However, another species, Erysiphe quercicola first described on oak in Japan by Takamatsu et al. (2007), was detected in about $20 \%$ of oak powdery mildew samples. Two other species, Erysiphe hypophylla and Phyllactinia roboris were far less frequent, representing only few percent of the samples (Mougou-Hamdane et al. 2010).

Oak powdery mildews infect young developing leaves in spring and summer. Indeed susceptibility of the leaf tissues 
strongly decreases as the leaf gets older (Edwards and Ayres 1982). Conidia are abundantly produced on infected leaves and are important for the infection of second and third leaf flush and the pathogen dispersal. In autumn, chasmothecia, the sexual structures, develop on the senescing leaves and are shed. Overwintering usually occurs in bark cracks and ascospores are produced in late spring (Marçais et al. 2009). Another overwintering mode is as mycelium in infected buds (Kerling, 1966; Yarwood, 1957). These infected buds develop in spring giving rise to so-called flags shoots, shoots that are severely infected by the pathogen with strong production of conidia. In a large survey in France, only $E$. quercicola was detected from flag shoot (Feau et al. 2011).

The initial impact of the disease at the beginning of the twentieth century was described as very severe, especially on coppices (Langhoffer 1929; Woodward et al. 1929; Foex 1941). Powdery mildew was reported to have different impact depending on the oak species. The most severely affected species was the so-called Pyrenean oak, Quercus pyrenaica (=Quercus toza), for which high mortality rates were observed in southwest and western France (Bureau 1908; Aubert 1919; Desprez-Loustau et al. 2011). Quercus robur was then reported as more susceptible than Quercus petraea while Mediterranean evergreen oaks, Quercus cerris and red oaks such as Quercus rubra and Quercus palustris were considered resistant (Woodward et al. 1929; Foex 1941). After a few years, the disease was considered less dramatic (Aubert 1919; Raymond 1927) and the authors wondered whether this could have been linked to a real decrease in the disease severity, because of less favourable climate or the action of mycoparasites or to a better appraisal of the disease long-term impact (Aubert 1919; Foex 1941). The disease is now well established but in spite of its frequent occurrence, its impact has often been considered as minor, except in a few situations (Delatour 1983; Thomas et al. 2002).

In this review, we will first examine the impact of powdery mildew on oaks, from the leaf to the plant level, distinguishing the young seedlings and the mature trees. As most available information refers to $Q$. robur and $Q$. petraea, we will mainly focus on impact of powdery mildew on these two species. Then, we will analyse the effect of environment. In conclusion, we will discuss the possible impact of climate change.

\section{Impacts of powdery mildew on oak trees}

\subsection{At leaf level}

The impact of powdery mildew at leaf level strongly depends on the timing and severity of infection, as leaf susceptibility depends on its age (Edwards and Ayres 1982). When infection occurs early in leaf development,
E. alphitoides induces necrosis and/or deformation of the leaf and can induce a reduced functional leaf area (Marçais and Bréda 2006; Hajji et al. 2009). An extreme impact of powdery mildew is leaf shedding. Indeed, severe powdery mildew infection, above $50 \%$ of the leaf surface, was shown to greatly reduce the infected leaf lifespan compared to healthy leaves (Hajji et al. 2009). The median time before shedding was estimated to be 10-31 days for oak leaves showing deformation or necrosis. As a consequence of severe infection, complete defoliation of the second and third growth unit formed in June and August has been reported in young oak seedlings (Jarvis 1964; Soutrenon 2003). This premature shedding could be a consequence of the altered water relations of infected leaves because their ability to reduce their temperature through stomatal conductance regulation is impeded (Hewitt and Ayres 1975; Hajji et al. 2009).

A more common consequence of powdery mildew infection is reduced carbon acquisition. As biotroph parasites, powdery mildew fungi acquire their nutrients from living host cells thanks to specialised feeding structures called haustoria (Divon and Fluhr 2007). Infection by powdery mildew thus results in the derivation of plant metabolism for fungal benefit. The impact of E. alphitoides on the leaf carbohydrate metabolism has been studied in detail. The pathogen was shown to reduce carbon assimilation $\left(A_{n}\right)$ and translocation of carbohydrates from the infected leaves to the rest of the plant (Hewitt and Ayres 1975, 1976; Percival and Fraser 2002; Hajji et al. 2009). The reduction of $A_{n}$ is linked to an impact of the infection on both maximal light driven electron flux $\left(J_{\max }\right)$ and on apparent maximal velocity of RuBP carboxylation ( $\mathrm{Vc}_{\max }$; Hajji et al. 2009). In the latter study, the decrease of $A_{n}$ in infected leaves was not compensated by an increased $A_{n}$ in the healthy leaves of the same seedling, leading to an overall reduction in carbon assimilation. However, the impact on leaf functioning was less than what could be expected from the observed fraction of leaf area infected: leaves with $100 \%$ leaf area affected by E. alphitoides still displayed levels of $A_{n}$ of about $50 \%$ of the value observed in healthy leaves (Hewitt and Ayres 1975; Brüggemann and Schnitzler 2001; Hajji et al. 2009). This is in contrast to what is generally observed for foliar pathogens where the impact on leaf physiology is greater than what would be expected from the fraction of the leaf affected (Bastiaans 1991). In particular, powdery mildews of wheat, pepper, peach, or grape have a greater impact on net photosynthesis than expected from the fraction of apparently affected area (Shtienberg 1992). In contrast, a less-thanproportional effect was reported for powdery mildew on soybean (Mignucci and Boyer 1979). In addition to changes in primary metabolism, powdery mildew infection also affects secondary metabolism, involved in plant defence. The inoculation of oak seedlings with E. alphitoides was associated with the accumulation of secondary metabolites 
such as phenols and lignins in the necrotic lesions and in adjacent cells in the infected oak leaves (Grzebyta et al. 2005).

\subsection{At the plant level}

Although the impact of E. alphitoides at the leaf level is very significant, the impact at the plant level is usually not considered as a problem (Delatour 1983; Thomas et al. 2002). It may be hypothesised that since oak trees are not grown for intensive wood production, only very high impacts, leading to mortality, are reported. Indeed, growth losses, which are likely to be caused in relation to effects on photosynthetic efficiency, are almost never documented for adult trees. The impact of disease on growth may itself be limited by the fact that the first growth unit produced by oaks in the spring generally escapes infection (Foex 1941; Soutrenon 1998). Because inoculum from chasmothecia is produced almost a month after the budburst, the disease is usually restricted to the second and third growth units that develop between end of June and August (Marçais et al. 2009). This strongly mitigates the severity and growth reduction impact of the disease, especially on large trees since the occurrence and importance (percentage of total leaf area) of second and subsequent growth flushes strongly declines with increasing tree age and size (Borchert 1976, Bréda et al. 1995). Moreover, conspicuous infection with entirely infected foliage may not have dramatic consequences at tree level since a significant fraction of the photosynthetic capacity is maintained, as seen before. However, reduced photosynthetic activity may lead to a reduction of plant carbohydrate reserves, which can result in delayed damage in subsequent years. The demand on carbohydrate reserves in spring before production of functional leaves is very high in oak trees since they produce a part of their annual ring before budburst. Limited photosynthesis ability in the previous growing season may therefore be critical (Barbaroux and Bréda 2002). In seedlings, severe shoot infection has been associated with changes in bud hardening and dormancy, leading to decreased cold resistance and increased susceptibility to secondary parasites, ultimately resulting in terminal shoot mortalities in the winter following infection (Ducomet 1913; Woodward et al. 1929; Foex 1941).

As a whole, severe impacts of oak powdery mildew have been reported in three main types of situations: (1) on trees with artificially modified growth patterns, such as coppice, pollard, and pruned trees; (2) on seedlings and saplings, especially in natural regenerations but also nurseries and plantations; (3) on mature trees, as a contributing factor of tree decline, especially after insect defoliation or frost damage.

The first situation was especially important in the early twentieth century when the first epidemics of oak powdery mildew were reported in Europe. Oak coppicing and pollarding have been commonly used for centuries as traditional methods of woodland management for the production of fuel wood or fodder for livestock. The very high impact of powdery mildew on pruned oak trees, in relation to the intense production of highly susceptible juvenile foliage, has been emphasised as an important factor explaining the catastrophic impact of the disease in the early twentieth century (Ducomet 1913; Raymond 1927; Foex 1941; Mougou et al. 2008). These practices have strongly declined during the second half of the twentieth century and now represent only a small part of oak stands. We will therefore focus on the impact of oak powdery mildew at juvenile stages, especially regeneration (i.e., young stands originating from seeds from cover trees), and as a contributing factor of tree decline in mature stands.

\subsubsection{Impact of powdery mildew in young oak stands}

A significant impact of oak powdery mildew has been reported on young seedlings, either in regeneration or nurseries (Doé 1919; Woodward et al. 1929; Anonymous 1956; Lanier et al. 1976; Murray 1974). Studies dealing with the regeneration of oaks have often emphasised the conspicuous powdery mildew infections, although the role of powdery mildew as a limiting factor of oak regeneration was not established in all situations (Jarvis 1964; Kelly 2002). In the French Forest Health Service database, spanning over the period 1990-2006, reports of damage in natural regenerations represent $38.8 \%$ of all oak powdery mildew disease reports. In accordance with the previously reported host preferences of E. alphitoides, the report rate is significantly higher for pedunculate oak than for sessile oak with $49.2 \%$ of the health problem reports in $Q$. robur regeneration being powdery mildew compared to $33.4 \%$ for $Q$. petraea $\left(\mathrm{Chi}^{2}=\right.$ $11.6, p$ value $<0.001$, unpublished results).

The impact of the pathogen in young oak stands was studied in more detail by Soutrenon $(1998,2003)$ in trials comparing oak performance under powdery mildew pressure with or without protection by fungicides. A first study over 6 years showed that powdery mildew infection had a significant impact on the growth of young planted $Q$. robur seedlings. The treatment of half of the planted seedlings with triadimenol at two dates per year (two applications at $10 \mathrm{ghl}^{-1}$ at the end of June and of August, on the second and third growth units) significantly improved their growth, both in height and diameter, although the treatment effect was significant only after 3 years of fungicide application (Soutrenon 1998). The biomass of treated seedlings was increased by $100 \%$ compared to the untreated seedlings. Protecting the seedlings against powdery mildew (with triadimenol at $10 \mathrm{ghl}^{-1}$ every 20 days since beginning of May for 3 years) in two natural regenerations also significantly 
improved their growth and survival (Soutrenon, 1998). Height growth of treated seedlings was increased by $25-$ $46 \%$ depending on the stand. However, although the number of dead seedlings was higher in the untreated plots, no figures of mortality could be computed because the seedlings were not individually followed. The strong impact of powdery mildew on oak regeneration was confirmed in a large-scale experiment in five forests over northern France (Soutrenon 2003). A single fungicide application (myclobutanil, $9 \mathrm{gl}^{-1}$ ) on the second growth unit during the first year of the regeneration was able to partially control the disease and to significantly increase seedling growth and survival. Depending on the forest and mainly on the disease severity, height growth was improved by $3-13 \%$ in the treated plots while seedling mortality was reduced by two- to threefold. In the forest with the highest severity (over $60 \%$ of the foliage infected in the untreated plots), seedling mortality reached $49 \%$ in untreated plots in comparison to $23 \%$ in treated plots 1 year after fungicide application. Moreover, these figures only represent a part of powdery mildew impact on the oak seedlings since only partial protection was afforded by the fungicide applications in all cases.

It has to be pointed out that Soutrenon $(1998,2003)$ used fungicide applications for experimental purposes in order to demonstrate the effect of powdery mildew on oak seedlings. The use of fungicides is usually not allowed in forest conditions and anyhow, their potential benefits are not obvious. Indeed, the improved growth and survival of seedlings has to be balanced against the cost of the treatment and its impact on the environment, especially fungal biodiversity. Although powdery mildew induced mortality can be very high in cases of severe infections, natural oak regenerations are usually very dense and the success of the regeneration will probably seldom be jeopardised by the pathogen. Moreover, the consequences of mortality, resulting in seedlings selection, might be to the advantage of the future stand if juvenile-adult correlations for powdery mildew resistance occur.

\subsubsection{Powdery mildew as a contributing factor of oak decline, especially in interaction with defoliation}

Severe impact of powdery mildew on trees that have been previously defoliated by insects has been well documented (Anonymous 1956; Delatour 1983). In the DSF database, $33.4 \%$ of all oak powdery mildew reports were made on trees that had their spring flush lost by insect defoliation or late frosts. Again, powdery mildew report rate was significantly higher for defoliated $Q$. robur compared to defoliated $Q$. petraea $\left(\mathrm{Chi}^{2}=4.8, p\right.$ value $=0.027$, unpublished results $)$. Monitoring of oaks stands that had previously suffered defoliation by insects in NE France during the 2001-2006 period showed that severe subsequent infection by powdery mildew occurred in more than $50 \%$ cases (Gerard et al. 2013).
Oak trees defoliated in their first flush (May-June) produce a secondary leaf flush later in spring or early summer. Thus, most of their leaf area is produced at a time when the availability of powdery mildew inoculum is high while mature trees usually produce their leaf in early spring under very low powdery mildew inoculum (Marçais et al. 2009). The infection of these newly produced leaves may be extremely severe, leading in the worst cases to a second defoliation (Marçais and Bréda 2006). Oak trees may then produce new leaves throughout the summer that are repeatedly destroyed by powdery mildew provided that conditions remain conducive to infection (Gerard et al. 2013). Experimental work on 20-year-old oaks artificially defoliated 2 years in a row demonstrated the negative synergistic impacts of defoliation and powdery mildew (Marçais and Bréda 2006). Trees strongly infected by E. alphitoides in summer after the manual defoliation showed lower starch reserve in the fall and suffered higher mortality than those that escaped infection. This critical importance of a severe infection by E. alphitoides following defoliation was confirmed by chemical treatment of defoliated trees to prevent the subsequent powdery mildew infection. Partial protection against $E$. alphitoides of 35-year-old $Q$. robur that had been defoliated by Thaumetopoea processionea using aerial application of fungicide improved their fate. Protected trees were significantly less infected by powdery mildew and in particular did not undergo a second defoliation due to the fungal infection. They suffered far less subsequent mortality with a $10 \%$ death rate 7 years after the fungicide treatment as compared to mortality of $37 \%$ for control unprotected oak trees (Gerard et al. 2013).

The major oak decline episode that occurred in the 1920s throughout Europe was attributed to the combination of defoliators and oak powdery mildew impacts by most authors (Falk 1924; Molleveaux 1926; Robinson 1927; Langhoffer 1929; Yossifovitch 1926). Although several other factors contributed to the decline depending on the location in Europe, the authors agreed that while oak trees might well overcome 1 year of combined defoliation by insects and powdery mildew, massive decline, and mortality is to be expected if the combined defoliation occurs 2 years in row. The majority of them stated that the insect defoliators alone had not had similar impact in the past despite regular episodes of intense defoliation (Falk 1924; Langhoffer 1929; Robinson 1927; Yossifovitch 1926). The emergence of $E$. alphitoides in Europe in 1907 thus dramatically amplified the negative impact of insect defoliations (Delatour 1983).

The interaction between insect defoliation and powdery mildew has been less frequently invoked to explain more recent oak declines (but see Selochnik et al. 1994, Thomas et al. 2002, Petercord 2011) while other inciting factors, especially drought and root pathogens have been put forward (Landmann et al. 1993; Brasier et al. 1993; Jung et al. 
2000; Marçais et al. 2000). However, insect defoliations remain very important causes of oak decline (Landmann et al. 1993, Thomas et al. 2002) and Gerard et al. 2013 showed that very severe powdery mildew infection were common after insect defoliations.

It has to be mentioned that powdery mildew has been associated with oak decline in a few cases not involving insect defoliation. These reports mostly concern so called "late oaks" (Molleveaux 1926), i.e., Q. robur that have a particular phenology, with a budburst delayed for 11.5 month in spring compared to the common date. Such "late oaks" have been reported in several European areas (Central France, Bulgaria) and appear to be an adaptation to soils severely waterlogged in spring and to late spring frost (Molleveaux 1926; Minkevich and Stoyanov 1987). The delayed budburst may promote severe infection of the first growth unit on mature trees with an associated severe impact of oak mildew. Severe mildew infection of oak trees with a late budburst has been mentioned as one of the inciting factors in the decline that occurred in 2001-2010 in the Vierzon forest in central France (Département de la Santé des Forêt, personal communication). The monitoring of oak tree phenology, powdery mildew infection, and decline in a stand of the Vierzon forest showed that the trees that had a late budburst suffered severe infection by $E$. alphitoides and had higher decline and mortality rates (Gerard et al. 2013).

\section{Influence of climate, microclimate, weather, and other environmental factors on the severity of oak powdery mildew}

The influence of weather factors on the severity of oak powdery mildew was discussed from the very beginning of oak powdery mildew epidemics in the early twentieth century. Several authors hypothesised that the sudden outbreak of the disease in Europe after several decades of sporadic occurrence might have been caused by exceptionally favourable weather conditions in 1907-1908 (Roux 1910; Raymond 1927). Subsequent variations of severity among years also suggested a climatic influence but no straightforward favourable or unfavourable seasonal weather variables could be defined as major explaining factors. It has also to be noted that oak powdery mildew rapidly spread to all European countries (and other continents) and has been established ever since in all regions in the range of its main hosts, deciduous oaks. It is therefore present in a wide range of climates, from Scandinavia to Russia and Eastern Europe, the British Isles, or Southern countries (Weltzien 1978). Arnaud (1921) suggested that powdery mildew species with a wide geographic range may find favourable conditions for their development almost anywhere at least at some periods of the year; the huge potential of these species for sporulation and dissemination would enable them to take advantage of these favourable periods to rapidly build up populations and expand. Microclimate can therefore be as important as local regional climate (Aust and HoyningenHuene 1986). This may explain why no clear picture of favourable climatic/microclimatic factors for the development of oak powdery mildew has emerged from studies of annual variations of disease or experimental studies.

\subsection{Effects of precipitations and moisture}

Many contradictions exist in the literature in regard to effects of moisture on powdery mildews although they are considered as a group as xerophilic fungal parasites (Raymond 1927; Yarwood 1957; Schnathorst 1965; Aust and Hoyningen-Huene 1986). This assumption however may be ambiguous since it does not mean that powdery mildews are systematically favoured by dry weather (Schnathorst 1965). Rather, it comes from the fact that, contrary to many other foliar fungi, free water is detrimental to the development of powdery mildews while they are usually able to tolerate moisture stress (Schnathorst 1965). Powdery mildew conidia have a very high water content, which may enable them to germinate even at low relative humidity (Yarwood 1957). In the case of E. alphitoides, the germination of conidia was shown to reach high levels on a wide range of relative humidity from 76 to $96 \%$, while a narrower optimum around $96 \%$ was observed for the elongation of germ tubes (Hewitt 1974). Several reports have pointed to the detrimental effects of rain on powdery mildew fungi, by washing-off spores and damaging mycelium at the leaf surface (Yarwood 1957; Aust and Hoyningen-Huene 1986; Jarvis et al. 2002). Sivapalan (1993), in a detailed study about the effects of free water on 36 powdery mildew species, showed that even for species such as E. alphitoides for which conidia were able to germinate as well in water as on host tissue (oak leaves), the ability of the fungus to establish a parasitic relationship with the host strongly decreased with the duration in water. Dry conditions are necessary for the release of conidia in the atmosphere (Schnathorst 1965; Jarvis et al. 2002; Glawe 2008). Conversely, the ejection of ascospores, the sexual spores acting as primary inoculum, produced in the overwintering form of the fungus (called chasmothecia), requires free moisture and occurs following rain events (Schnathorst 1965; Glawe 2008). Epidemics of oak powdery mildew are hardly related to typically dry years (Raymond 1927; Selochnik et al. 1994). Some authors even suggested that the outbreak of the disease in the early twentieth century could be linked to unusually rainy years (Roux 1910). Basova (1987), in a study of annual variations in oak powdery mildew severity in the region of Voronezh (Russia), 
concluded that severe levels of infections are associated with "moderate" levels of humidity and precipitations (70$80 \mathrm{~mm} / \mathrm{month}$ ) during the growing season. Selochnik et al. (1994) in the same region also observed that epidemics were associated with a sufficient level of rains in spring.

\subsection{Effects of light}

The literature about light effects on powdery mildews also includes many conflicting reports. As epiphytic pathogens, powdery mildews are exposed to incident radiation on the leaf surfaces. Their tolerance is all the more remarkable that their mycelium and spores are hyaline, i.e., they are not protected by pigments (Arnaud 1921; Yarwood 1957). The detrimental effects of UV-B have been shown on several powdery mildew species (Willocquet et al. 1996; Roberts and Paul 2006) but a reverse relationship was observed for E. alphitoides. (Newsham et al. 2000) observed that exposure to increased UV-B led to increased powdery mildew infection on oak seedlings. In a preliminary experiment, we also observed that seedlings placed under a filter blocking UV-B radiation were less infected than seedlings exposed to full sunlight (unpublished results). A number of authors reported that shading is generally favourable for powdery mildew development (Arnaud 1921, Schnathorst 1965; Jarvis et al. 2002). However, some observations have suggested effects in the opposite direction, especially for oak powdery mildew. Ducomet (1913) reported that infection was favoured by diffuse light intensity in the laboratory but observed that, in Western France, oak infection was more severe near edges or clearings in coppices with standards. Higher severity of powdery mildew infection on oak trees in open compared to shady sites was mentioned by Raymond (1927) in France and Selochnik et al. (1994) in Russia. Kelly (2002) in Ireland also reported that infection was more widespread and severe on seedlings in the clearing than in shaded plots. Giertych and Suszka (2010) using potted seedlings growing under different light conditions obtained maximum damage in full light. Experimental studies using lowenergy light-emitting diodes have shown that not only light intensity but also light quality (spectral composition), which may be changed by canopy shade (Endler 1993), is an important factor influencing powdery mildew development. Interestingly, an inhibitory effect of wavelengths corresponding to red light $(650-750 \mathrm{~nm})$ was shown for several species (Schuerger and Brown 1997; Suthaparan et al. 2010). This has not yet been studied for oak powdery mildew. However, our observations of higher success of oak inoculations in growth chambers with metal halide lamps than in those with sodium lamps, which generate more light in the orange-red spectrum, are consistent with this (unpublished data). Conflicting reports about the effects of light may be explained by the interactions with other factors: light effects are difficult to isolate from moisture and temperature effects. In particular, sunlight exposure is associated both with increased incident radiation, including UV, and with leaf warming (Aust and Hoyningen-Huene 1986). YashewRaguenes (unpublished data) observed that seedling infection in a natural oak regeneration in southern France was highest in plots with intermediate levels of light interception (around $50 \%$ of incident radiation) by mother trees. This result might be explained by an inhibitory effect of high temperatures on the surface of leaves exposed to full sunlight (Aust and Hoyningen-Huene 1986). Discrepancies in the effects of environmental factors can also be explained by indirect effects through host physiology, which are especially important for biotroph parasites such as powdery mildews (Aust and Hoyningen-Huene 1986; Jarvis et al. 2002). Ducomet (1913) explained the contradictory observations about light effects on oak powdery mildew infection in the laboratory and in the field by differences in plant growth dynamics. Jarvis (1964) and Kelly (2002) noted that even if powdery mildew infection on oak seedlings was more severe in open areas, its impact was more important at low light intensity, where the performance of seedlings was less. This resulted in a higher light intensity necessary for seedling survival when powdery mildew infection was significant. Indirect effects may act not only through the host. Newsham et al. (2000) suggested that the favourable effect of UV-B on powdery mildew in their experiment might be explained by a decrease in the antagonistic epiphytic microflora.

\subsection{Temperature}

The development of oak powdery mildew occurs on a wide range of temperatures. Under controlled conditions, Hewitt (1974) obtained high levels of conidia germination from 15 to $25{ }^{\circ} \mathrm{C}$, with an optimum at $20-23{ }^{\circ} \mathrm{C}$, while germ tube elongation occurred on the same range with an optimum at $25{ }^{\circ} \mathrm{C}$; no germination and germ tube elongations were observed at $30{ }^{\circ} \mathrm{C}$. Colony growth under controlled conditions was observed from $10{ }^{\circ} \mathrm{C}$ to $30^{\circ} \mathrm{C}$, with an optimum at 22-30 ${ }^{\circ} \mathrm{C}$ and cessation of growth at $34{ }^{\circ} \mathrm{C}$ (DesprezLoustau et al. 2010b). In natural conditions, Basova (1987) reported that a massive development of oak powdery mildew was favoured by a temperate climate, with mean temperatures of $16-21{ }^{\circ} \mathrm{C}$ in the growing season. Selochnik et al. (1994) mentioned an optimum disease development for mean temperature in June around $20{ }^{\circ} \mathrm{C}$. Winter temperatures could also be an important factor in the epidemiology of oak powdery mildew (Desprez-Loustau et al. 2010b). A study of spatiotemporal distribution of oak powdery mildew reports from mature stands where no defoliation by insects or late frost had been reported $(27.8 \%$ of the oak mildew reports in the DSF database) showed that the best explaining variable was mean temperature in January-February-March 
(Fig. 1). More precisely, the three epidemic peaks observed in 1990, 1997, and 2001 (Fig. 1a) were associated with high mean winter temperature (Fig. 1b). The possible mechanism by which mild winter temperature could favour oak powdery mildew remains poorly understood. Winter temperature can have an important effect on the perennation of powdery mildew fungi in the absence of susceptible hosts (Jarvis et al. 2002). For grapevine and apple powdery mildew, it is thought that chasmothecia (sexual organs) are the predominant overwintering form in regions with cold winters whereas the fungus survives as mycelium in dormant buds in milder areas (Jarvis et al. 2002). This might be explained by a higher sensitivity of infected buds to low temperatures (Jarvis et al. 2002). However, Feau et al. (2011) could not observe any geographic pattern in flag shoot frequency (resulting from the development of infected buds) in oak regenerations in an extensive survey in France. Relatively
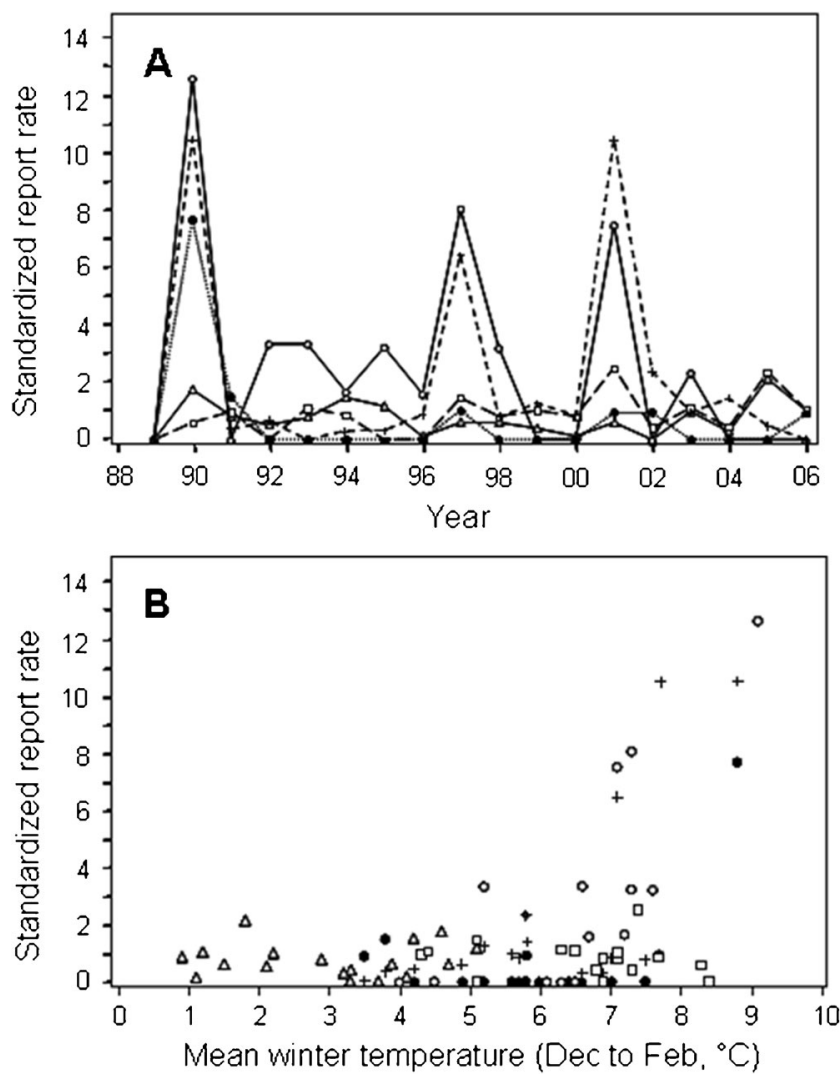

Fig. 1 Report of powdery mildew on adult $Q$. petraea, $Q$. pubescens, and $Q$. robur (trees not previously defoliated by insects, DSF database, 1989-2006). The standardised report rate is the ratio for a given region of raw number of disease reports to an expected number of disease reports. a Evolution of the standardised report rate in each ecoregion. b Relationship between Oak mildew report and mean air temperature in December, January, and February. (-o- 0 ) Pyrenean piedmont; $(-+-,++)$ Southwest lowlands; (---,ㅁ) Western lowlands; $(\cdots \cdot \cdot \cdot \cdots \cdot . \cdot, 0)$ Massif Central; $(\neg-, \Delta)$ Northeastern lowlands. The standardised report rate is computed as explained in Fabre et al. (2011) high frequencies of flag shoots were sometimes observed in areas with continental climate.

\subsection{Other environmental factors}

The effects of other environmental factors such as $\mathrm{CO}_{2}$, soil characteristics, or biotic environment in the phyllosphere have been little documented specifically for oak powdery mildew but have been described for other species of Erysiphales (Jarvis et al. 2002). It is generally assumed that powdery mildew disease severity is closely and positively related to host vigour and tenderness. Thus all factors promoting these will predispose the plant to high infection (Jarvis et al. 2002). Conversely, a negative effect of air pollution was shown on the development of oak powdery mildew (Grzywacz and Ważny 1973; Sucharzewska 2009), which may be linked to high $\mathrm{SO}_{2}$ concentrations.

In addition, the severity of oak powdery mildew might be regulated by the activity of hyperparasites such as Ampelomyces quisqualis. The role of such natural regulation to explain the decline in disease severity in the years following its emergence at the beginning of the twentieth century was hypothesised by several authors (Ducomet 1913; Raymond 1927). Recent studies suggest that A. quisqualis is a complex of specialised species adapted to the phenology of their fungal hosts (Kiss et al. 2011). This question remains to be explored in more detail for the different cryptic species causing oak powdery mildew.

\section{Conclusion: the critical importance of host-pathogen phenological synchrony and possible impacts of climate change}

Observations and available knowledge on oak powdery mildew point to the critical importance of the host tree growth patterns to explain the severity of the disease, since only young developing leaves are susceptible. As pointed previously, infection is high mainly on the second and third growth units whereas the first growth unit usually escapes infection (Foex 1941; Soutrenon 1998).

This may be explained by the late availability of inoculum in spring. Indeed, the peak of ascospore production from chasmothecia, which represent the primary inoculum re-initiating the annual epidemics, was shown to occur up to 30-50 days after budburst of the first oak flush in several French locations (Marçais et al. 2009; Desprez-Loustau et al. 2010a). Phenological synchrony between host growth and ascospore production was shown to be an important factor explaining disease severity for $Q$. petraea (DesprezLoustau et al. 2010a). Mycelial overwintering in oak buds, which causes the flag-shoot symptom, would theoretically 
provide a perfect synchrony. This symptom has been reported in several European regions (Woodward et al. 1929; Foex 1941; Kerling 1966). A recent survey showed that this particular life cycle is infrequent in France $(0.2-0.5 \%$ of the seedlings in about $50 \%$ of oak natural regenerations) and is strictly associated with E. quercicola (Feau et al. 2011). The relationship between occurrence of E. quercicola and disease severity remains however to be investigated.

The constraint on phenological synchrony between host and pathogen may be relaxed in some situations when trees produce a significant part of their foliage under high inoculum availability. This occurs in young seedlings, with repeated shoot flushes, in trees previously defoliated by insects or late frost, pruned trees, including late coppice clear-cuts, or in trees with late budburst (among which trees in the understory), and it was shown to lead to very severe powdery mildew infection. A very late budburst, compared to other oak species, could also explain the very high severity of the disease on $Q$. pyrenaica. The importance of phenological synchrony in biotic interactions has been the subject of considerable work for organisms that specialise on an ephemeral resource such as developing leaves, in particular for defoliating insects (Van Ash and Visser 2007). Since climate change is particularly characterised by a global warming and spring phenology of most organisms is driven by temperature, important changes in phenology are expected to occur and were indeed the first biological evidence of climate change (Parmesan 2006). Furthermore, disruption in phenological synchrony could occur in some interactions, in particular if both partners do not respond in a similar way to temperature (Van Ash and Visser 2007; Both et al. 2009). Indeed, E. alphitoides was shown to respond less strongly to a temperature gradient than its host $Q$. petraea, resulting in differences in synchrony and disease severity along the gradient (Desprez-Loustau et al. 2010a). Increased phenological synchrony might be an explanation for the high report of powdery mildew on mature nondefoliated oaks in southwest France in mild years such as 1990, 2001, and 2007 (see §2.3).

A better understanding of the climate dependence of the $E$. alphitoides/oak phenological synchrony and its effect on disease severity is required in order to predict potential effects of climate change. Modelling host-parasite phenological synchrony in spring with future climate scenarios should soon be feasible, by combining outputs of oak phenological model (Chuine 2000) with a powdery mildew phenological model (Marçais et al. 2009). However, a proper estimate of the resulting impact on mature oaks is a challenge. Indeed, if the impact of very severe infection that may occur in interaction with insect defoliation is well understood, the impact of less acute infection is difficult to assess and will require the acquisition of data by fine monitoring. Empirical models relating growth reduction to levels of infection will not be easy to develop, given the difficulty to have a reference growth level (i.e., not affected by infection) by efficiently protecting mature trees by fungicide application. Moreover, known impact of powdery mildew on oaks in a particular situation might be difficult to extrapolate to different sites or climatic conditions if the mechanisms which lead to this impact are not well understood (Pinkard et al. 2011). Process-based models coupling tree physiology with the pathogen dynamics and effects are thus required in order to estimate the impact of disease on carbon assimilation by the trees and net stand productivity in interaction with climate. Such models have been developed on other forest trees and were shown to adequately estimate the impact of leaf pathogen or pest on tree productivity (Battaglia et al. 2011).

Funding This work was supported by the French research founding agency ANR programme "Vulnérabilité et climat" via the DRYADE project, ANR-06-VULN-004 and by the GICC (Groupe Intergouvernemental sur le Changement Climatique) project FAST.

Open Access This article is distributed under the terms of the Creative Commons Attribution License which permits any use, distribution, and reproduction in any medium, provided the original author (s) and the source are credited.

\section{References}

Anonymous (1956) Oak mildew. Forestry Commission Leaflet no. 38 Arnaud G (1921) Study on parasite fungi (Parodiellinaceae, including Erysiphaea (in French). Ann Epiphyt 7:1-115

Aubert CG (1919) Powdery mildew and forests of western France (in French). Rev Eaux Forêts 57:189-195

Aust HJ, Hoyningen-Huene J (1986) Microclimate in relation to powdery mildew epidemics. Annu Rev Phytopathol 24:491-510

Barbaroux C, Bréda N (2002) Contrasting distribution and seasonal dynamics of carbohydrate reserves in stem wood of adult ringporous sessile oak and diffuse-porous beech trees. Tree Physiol 22:1201-1210

Basova SV (1987) Seasonal dynamics of powdery mildew of pedunculate oak in a seed grafting plantation (in Russian). Mikol Fitopatol 21:269-273

Bastiaan L (1991) Ratio between virtual and visual lesion size as a measure to describe reduction in leaf photosynthesis of rice due to leaf blast. Phytopathology 81:611-615

Battaglia M, Pinkard EA, Sands PJ, Bruce JL, Quentin A (2011) Modelling the impact of defoliation and leaf damage on forest plantation function and production. Ecol Modelling 222:31933202

Borchert R (1976) Differences in shoot growth patterns between juvenile and adult trees and their interpretation based on systems analysis of trees. Acta Hort 56:123-130

Both C, Van Ash M, Bijlsma RG, Van Den Burg AB, Visser ME (2009) Climate change and unequal phenological changes across four trophic levels: constraints or adaptations? J Animal Ecol 78:73-83

Brasier CM, Robredo F, Ferraz JFP (1993) Evidence for Phytophthora cinnamomi involvement in Iberian oak decline. Plant Pathol 42:140-145 
Bréda N, Granier A, Aussenac G (1995) Effects of thinning on soil and tree water relations, transpiration and growth in an oak forest (Quercus petraea). Tree Physiol 15:295-306

Brüggemann N, Schnitzler JP (2001) Influence of powdery mildew (Microsphaera alphitoides) on isoprene biosynthesis and emission of pedunculate oak (Quercus robur L.) leaves. J Appl Bot 75:91-96

Bureau E (1908) Impact of Oidium quercinum on different oak species. CR Hebd Scéances Acad Sci 10:268 (in French)

Chuine I (2000) A unified model for tree phenology. J Theor Biol 707:337-347

Delatour C (1983) Oak declines in Europe (in French). Rev For Franc 35:265-282

Desprez-Loustau ML, Vitasse Y, Delzon S, Capdevielle X, Marçais B, Kremer A (2010a) Are plant pathogen populations adapted for encounter with their host? A case study of phenological synchrony between oak and an obligate fungal parasite along an altitudinal gradient. J Evol Biol 23:87-97

Desprez-Loustau ML, Robin C, Reynaud G, Déqué M, Badeau V, Piou D, Husson C, Marçais B (2010b) Simulating the effects of a climate change scenario on geographical range and activity of forest pathogenic fungi. In: Loustau D (ed) Response of temperate and Mediterranean forests to climate change: effects on carbon cycle, productivity and vulnerability. QUAE, Paris, pp 253-280

Desprez-Loustau M-L, Feau N, Mougou-Hamdane A, Dutech C (2011) Interspecific and intraspecific diversity in oak powdery mildews in Europe: coevolution history and adaptation to their hosts. Mycoscience 52:163-175

Divon HH, Fluhr R (2007) Nutrition acquisition strategies during fungal infection of plants. FEMS Microbiol Letters 266:65-74

Doé F (1919) [The conversion of coppice with standard into high forest and powdery mildew] (in French). Rev Eaux Forêts 57:53-59

Ducomet V (1913) Research on oak and chestnut diseases in Brittany (in French). Ann Epiphyt 1:87-105

Edwards MC, Ayres PG (1982) Seasonal changes in resistance of Quercus petraea (sessile oak) leaves to Microsphaera alphitoides. Trans Br Mycol Soc 78:569-571

Endler JA (1993) The color of light in forests and its implications. Ecol Monographs 63:1-27

Fabre B, Ioos R, Piou D, Marçais B (2011) Is emergence of pine Dothistroma needle blight in France caused by the cryptic species Dothistroma pini. Phytopathology 102:47-54

Falk R (1924) Oak dieback in the Straslund district and contribution to the biology of Armillaria and powdery mildew in German. Allg Forst Jagdz 100:298-317

Feau N, Lauron-Moreau A, Piou D, Marçais B, Dutech C, DesprezLoustau ML (2011) Niche partitioning of genetic lineages involved in the oak powdery mildew complex. Fung Ecol 5:154-162

Foex ME (1941) Invasion of European oaks by the powdery mildew (in French). Rev Eaux Forêts 79:338-349

Gerard B, Caël O, Mandret X, Bréda N, Marçais B (2013) Disturbances in the leaf area index dynamics increases oak's vulnerability to powdery mildew and therefore the risk of decline. Ann For Sci (in press)

Giertych MJ, Suszka J (2010) Influence of cutting off distal ends of Quercus robur acorns on seedling growth and their infection by the fungus Erysiphe alphitoides in different light conditions. Dendrobiology 64:73-77

Glawe DA (2008) The powdery mildews:a review of the world's most familiar (yet poorly known) plant pathogens. Annu Rev Phytopathol 46:27-51

Grzebyta J, Karolewski P, Zytkowiak R, Giertych MJ, Werner A, Zadworny M, Oleksyn J (2005) Effects of elevated temperature and fluorine pollution on relations between the pedunculate oak (Quercus robur) and oak powdery mildew (Microsphaera alphitoides). Dendrobiology 53:27-33
Grzywacz A, Ważny J (1973) The impact of industrial air pollutants on the occurrence of several important pathogenic fungi of forest trees in Poland. Eur J For Pathol 3:129-141

Hajji M, Dreyer M, Marçais B (2009) Impact of Erysiphe alphitoides on transpiration and photosynthesis in Quercus robur leaves. Eur J Plant Pathol 125:63-72

Hewitt HG (1974) Conidial germination in Microsphaera alphitoides. Trans Br Mycol Soc 63:587-628

Hewitt HG, Ayres PG (1975) Changes in $\mathrm{CO}_{2}$ and water vapour exchange rates in leaves of Quercus robur infected by Microspheara alphitoides (powdery mildew). Physiol Plant Pathol 7:127-137

Hewitt HG, Ayres PG (1976) Effect of infection by Microsphaera alphitoides (powdery mildew) on carbohydrate levels and translocation in seedlings of Quercus robur. New Phytolol 77:379-390

Jarvis PG (1964) The adaptability to light intensity of seedlings of Quercus petraea. J Ecol 52:545-571

Jarvis WR, Gubler WD, Grove GG (2002) Epidemiology of powdery mildews in agricultural pathosystems. In: Bélanger RR, Bushnell WR, Dik AJ, Carver TLW (eds) The powdery mildews. A comprehensive treatise. APS Press, St. Paul, pp 169-199

Jung T, Blaschke H, Oswald W (2000) Involvement of soilborne Phytophthora species in Central European oak decline and the effect of site factors on the disease. Plant Pathol 49:706-718

Kelly DL (2002) The regeneration of Quercus petraea (sessile oak) in southweat Ireland: a 25-year experimental study. For Ecol Manag 166:207-226

Kerling L (1966) The hibernation of the oak mildew. Acta Bot Neerl 15:76-83

Kiss L, Pintye A, Kovács GM, Jankovics T, Fontaine MC, Harvey N, Xu X, Nicot PC, Bardin M, Shykoff JA, Giraud T (2011) Temporal isolation explains host-related genetic differentiation in a group of widespread mycoparasitic fungi. Mol Ecol 20:1492-1507

Langhoffer A (1929) Oak decline in Yougoslavia, especially in Slavonia (in French). Rev Eaux Forêts 37:763-764

Landmann G, Becker M, Delatour C, Dreyer E, Dupouey JL (1993) Oak dieback in France: historical and recent records, possible causes, current investigations. In: Rundgespräche der Kommission für Ökologie, Bd. 5 'Zustand und Gefährdung der Laubwälder', pp. 97-114

Lanier L, Joly P, Bondoux P, Bellemère A (1976) Pathology of broadleaf trees species (in French). Mycologie et Pathologie forestière, Masson, In, pp 311-320

Marçais B, Caël O, Delatour C (2000) Relationship between aboveground signs and symptoms and root infection by Collybia fusipes in oaks. For Pathol 30:7-17

Marçais B, Bréda N (2006) Role of an opportunistic pathogen in the decline of stressed oak trees. J Ecol 94:1214-1223

Marçais B, Kavkova M, Desprez-Loustau ML (2009) Phenotypic variation in the phenology of ascospore production between European populations of oak powdery mildew. Ann For Sci 66:814-822

Mignucci JS, Boyer JS (1979) Inhibition of photosynthesis and transpiration in soybean infected by Microsphaera diffusa. Phytopathology 69:227-230

Minkevich II, Stoyanov SM (1987) Prevision of the development of oak powdery mildew based on the phenology of the host plant in Bulgaria. Izvestiya Vysshikh Zavedenij, Lesnoj Zhurnal 3:114 116 (in Bulgarian)

Molleveaux J (1926) [The demise of late oak in Vierzon] (in French). Rev Eaux Forêts 64:614-617

Mougou A, Dutech C, Desprez-Loustau ML (2008) New insights into the identity and origin of the causal agent of oak powdery mildew in Europe. For Pathol 38:275-287

Mougou-Hamdane A, Giresse X, Dutech C, Desprez-Loustau ML (2010) Spatial distribution of lineages of oak powdery mildew fungi in France, using quick molecular detection methods. Ann For Sci 67:212 
Murray JS (1974) The fungal pathogens of oak. In: Morris MG, Perrin FH (eds) The British oak: its history and natural history. Botanical society of the British Isles \& EW Classey, Faringdon, Berkshire

Newsham KK, Oxborough K, Greenslade PD, McLeod AR (2000) UV-B radiation constrains the photosynthesis of Quercus robur through impacts on the abundance of Microsphaera alphitoides. For Pathol 30:265-275

Parmesan C (2006) Ecological and evolutionary responses to recent climate change. Annu Rev Ecol Evol Syst 37:637-669

Percival GC, Fraser GA (2002) The influence of powdery mildew infection on photosynthesis, chlorophyll fluorescence, leaf chlorophyll and carotenoid content of three woody plant species. Arboricultural Journal 26:333-346

Petercord R (2011) Damage on oak after insect infestation and mildew infection in Lower and Middle Franconia (in German). Forstschutz Aktuell 51:19-21

Pinkard EA, Battaglia M, Roxburgh S, O’Grady AP (2011) Estimating the net primary production under changing climate: adding pest into the equation. Tree Physiol 31:686-699

Raymond J (1927) Oak powdery mildew (in French). Ann Epiphyt 13:94-129

Roberts MR, Paul ND (2006) Seduced by the dark side: integrating molecular and ecological perspectives on the influence of light on plant defence against pests and pathogens. New Phytol 170:677-699

Robinson RL (1927) Mortality among oaks. Quaterly J For 21:25-27

Roux C (1910) [Oak powdery mildew] (in French). Annales de la Société d'Agriculture, Science et Industrie IV:251-258

Schnathorst WC (1965) Environmental relationships in the powdery mildews. Annu Rev Phytopathol 3:343-366

Schuerger AC, Brown CS (1997) Spectral quality affects disease development of three pathogens on hydroponically grown plants. Hort Sci 32:96-100

Selochnik NN, Il'yushenko AF, Kondrashova NK (1994) Powdery mildew of oak and its distribution in the stand canopy (in Russian). Lesovedenie 4:61-70

Sivapalan A (1993) Effect of water on germination of powdery mildew conidia. Mycol Res 97:71-76
Shtienberg D (1992) Effects of foliar diseases on gas exchange processes: a comparative study. Phytopathology 82:760-765

Soutrenon A (1998) [A pluriannual experiment confirms the impact of powdery mildew on young seedlings] (in French). Les cahiers du DSF, 1-2000 (la santé des forets [France] en 1997), Min. Agri. Pêche (DERF), Paris, 93-94

Soutrenon A (2003) [Evaluation of the interest of a chemical treatment againt oak powdery mildew in natural regeneration] Document CEMAGREF, 19p (in French)

Sucharzewska E (2009) The development of Erysiphe alphitoides and E. hypophylla in the urban environment. Acta Mycol 44:109-123

Suthaparan A, Torre S, Stensvand A, Herrero ML, Pettersen RI, Gadoury DM, Gislerød HR (2010) Specific light-emitting diodes can suppress sporulation of Podosphaera pannosa on greenhouse roses. Plant Dis 94:1105-1110

Takamatsu S, Braun U, Limkaisang S, Kom-Un S, Sato Y, Cunnington JH (2007) Phylogeny and taxonomy of the oak powdery mildew Erysiphe alphitoides sensu lato. Mycol Res 111:809-826

Thomas FM, Blank R, Hartmann G (2002) Abiotic and biotic factors and their interactions as causes of oak decline in central Europe. For Pathol 32:277-307

Van Ash M, Visser ME (2007) Phenology of forest caterpillars and their host trees: the importance of synchrony. Annu Rev Entomol 52:37-55

Weltzien HC (1978) Geographical distribution of powdery mildews. In: Spencer DM (ed) The powdery mildews. Academic, London, pp 39-49

Willocquet L, Colombet C, Rougier M, Fargues J, Clerjeau M (1996) Effects of radiation, especially ultraviolet $\mathrm{B}$, on conidial germination and mycelial growth powdery mildew. Eur J Plant Pathol 102:441-449

Woodward RC, Waldie JSL, Steven HM (1929) Oak mildew and its control in forest nurseries. Forestry 3:38-56

Yarwood CE (1957) Powdery mildews. Bot Rev 23:235-300

Yossifovitch M (1926) [Oak decline ( $Q$. pedunculata) in the forests of Slavonia (Yougoslavia)] (in Serbo-Croatian). Rev Eaux Forêts. pp 288-291 